\title{
Lateral intercrural suture in the caucasian nose: Decreased domal divergence angle in endonasal rhinoplasty without delivery
}

\author{
Sutura intercrura lateral no nariz caucasiano: Estruturação e diminuição do ângulo de \\ divergência domal na rinoplastia endonasal sem delivery
}

\author{
Cezar Augusto Sarraf Berger', Marcos Mocelin², Caio Márcio Correia Soares ${ }^{3}$, Rogério Pasinato ${ }^{4}$, Andreia Ellery Frota ${ }^{5}$. \\ 1) Master in Surgical. Voluntary Professor, Department of Otorhinolaryngology, Federal University of Parana. Otolaryngologist Hospital IPO. \\ 2) Entitled Professor of Otolaryngology at Federal University of Parana State (UFPR). Doctor of IPO Hospital. Parana Institute of Otolaryngology Hospital. Entitled Professor \\ of Otolaryngology Department of Federal University of Parana /UFPR. Otolaryngologist Doctor of IPO Hospital. \\ 3) Master in Surgical.Otolaryngologist, Department of Otorhinolaryngology, Federal University of Parana (UFPR) and the Hospital IPO. \\ 4) Master. Adjunct Professor of Otolaryngology Department of Federal University of Parana/UFPR. Otolaryngologist Doctor of IPO Hospital /Parana Institute of \\ Otolaryngology Hospital. \\ 5) Expert in Otolaryngology. Otolaryngologist Doctor. Ex-Fellow of Surgery for Facial Plastics of IPO Hospital / Parana Institute of Otolaryngology Hospital. \\ Institution: Instituto Paranaense de Otorrinolaringologia. \\ Curitiba / PR - Brazil. \\ Mailing address: Cezar Augusto Sarraff Berger - República Argentina Avenue, 2069 - Bairro Água Verde - Curitiba / PR - Brazil - Zip-code: 80620-010 - Telephone: \\ (+55 41) 3314-1503 - E-mail: nep@ipo.com.br \\ Article received in October 14, 2011. Article approved in February 21, 2012.
}

\section{SUMMARY}

Introduction: Several techniques can be performed to improve nasal tip definition such as cartilage resection, tip grafts, or sutures.

Objctive: To evaluate the outcome of lateral intercrural suture at the lower lateral cartilage by endonasal rhinoplasty with a basic technique without delivery in decreasing the angle of domal divergence and improving the nasal tip definition.

Method: This prospective study was performed in 64 patients in which a suture was made on the board head of the lower lateral cartilage in the joint between the dome and lateral crus, using polydioxanone (PDS) with sharp, curved needle.

Results: In all of the cases, better definition of the nasal tip was achieved by intercrural suturing for at least 6 months postoperatively.

Conclusion: Lateral intercrural suture of the lower lateral cartilage provides improved nasal tip definition and can be performed by endonasal rhinoplasty without delivery in the Caucasian nose.

Keywords: sutures, rhinoplasty, nasal cartilage.

\section{RESUMO}

Introdução: Diversas técnicas podem ser realizadas para melhorar a definição da ponta nasal como ressecção cartilaginosa, colocação de enxertos ou suturas. A realização de suturas na ponta nasal proporciona resultados estéticos satisfatórios com menor morbidade 1-5.

Objetivo: Avaliar a sutura intercrura lateral realizada na cartilagem lateral inferior, através de rinosseptoplastia endonasal por técnica básica sem delivery, para diminuição do ângulo de divergência domal no nariz caucasiano e consequente melhora na definição da ponta nasal.

Método: Realizado estudo prospectivo com 64 casos nos quais foi confeccionada sutura no bordo cefálico da cartilagem lateral inferior na junção entre a cúpula e crus lateral, utilizando-se fio P.D.S. (Polydioxanorie ${ }^{\circledR}$ ) incolor 4"0" com agulha curva cortante. Resultado: Foram analisadas e comparadas as fotos do pré - operatório e do pós -operatório com 6 meses de evolução. Em todos os casos foi atingida uma melhora na definição da ponta através da sutura intercrura lateral.

Conclusão: A sutura intercrura lateral da cartilagem lateral inferior mostrou ser factível para uma melhor definição da ponta no nariz caucasiano podendo ser realizada por rinoplastia endonasal sem delivery.

Palavras-chave: suturas, rinoplastia, cartilagens nasais. 


\section{INTRODUCTION}

Nasal tip surgery represents a challenge to rhinoseptoplasty. Several techniques can be performed to improve the defination of the nasal tip such as cartilaginous resection, tip grafts, or suture placement. Resection techniques have gradually been replaced by maneuvers that are more effective in preserving the nasal tip support mechanisms (1-10).

The aim of study is evaluate the outcome of lateral intercrural suture at the lower lateral cartilage (LLC) of the Caucasian nose through endonasal rhinoplasty using a basic technique without delivery to decrease the angle of domal divergence and improve the definition of the nasal tip.

\section{METHOD}

The present study was carried out between the years of 2008 and 2009 at the Parana Institute for Otorhinolaryngology (IPO) Hospital in the city of Curitiba. From a 100-patient sample, we excluded those who had a history of nasal surgery, previous nasal trauma, and a nonCaucasian nose. Sixty-four patients participated of the study, including 43 males and 21 females that were between 16 and 59 years old $(m=37.5)$. All of the patients had knowledge of the study and signed a Free Informed Term of Consent (FITC) form in compliance with the Brazilian Federal Ruling of National Concill of Health (CNS) 196/96.

We used the Converse-Diamond (1), which is a classic rhinoseptoplasty surgical technique. The nasal tip was accessed through septocolumelarand intercartilaginous incisions. In all cases, La Garde's maneuver was performed without resection of the cephalic border of the LLC (the McIndoetechnique).

The lateral intercrural suture must be performed on the cephalic border of LLC through the intecartilaginous incision, on the junction between the dome and lateral crus (Figure 1), and its grip must be gradual and progressive, thus allowing for adjustments to achieve the most appropriate tip (Figure 2).

The lateral intercrural suture must be done after the septocolumelar suture and before the intercartilaginous suture, using colorless Polydioxanone ${ }^{\circledR} 4$ '0' (PDS) with a sharp, curved needle. Performing the intercrural stitch at the end of the surgery avoids excessive manipulation of the tip and possible enlargement of the interdomal distance (the angle of domal divergence).

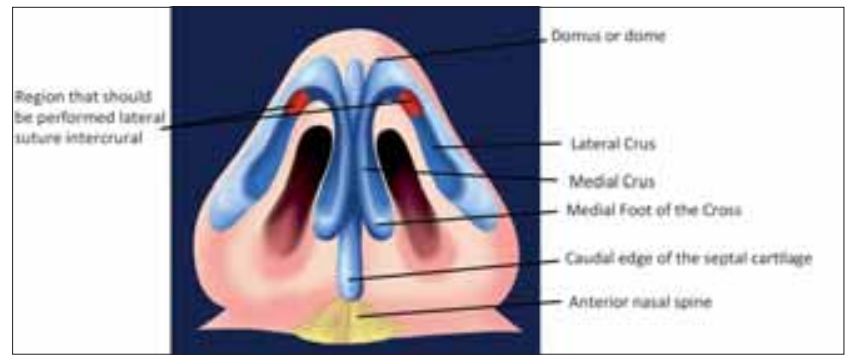

Figure 1. Surgical anatomy of the nasal tip.
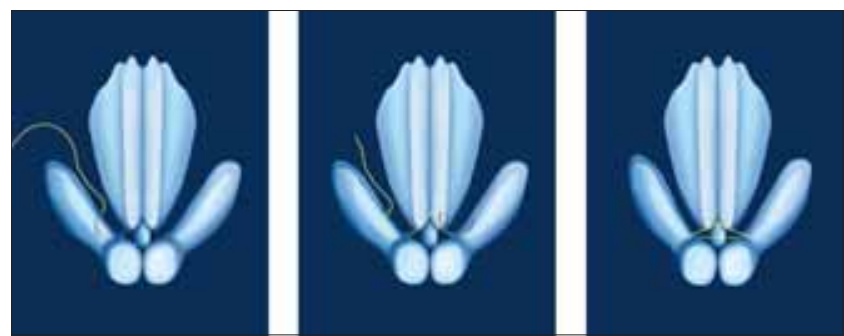

Figure 2. Fabrication of the lateral intercrural suture.

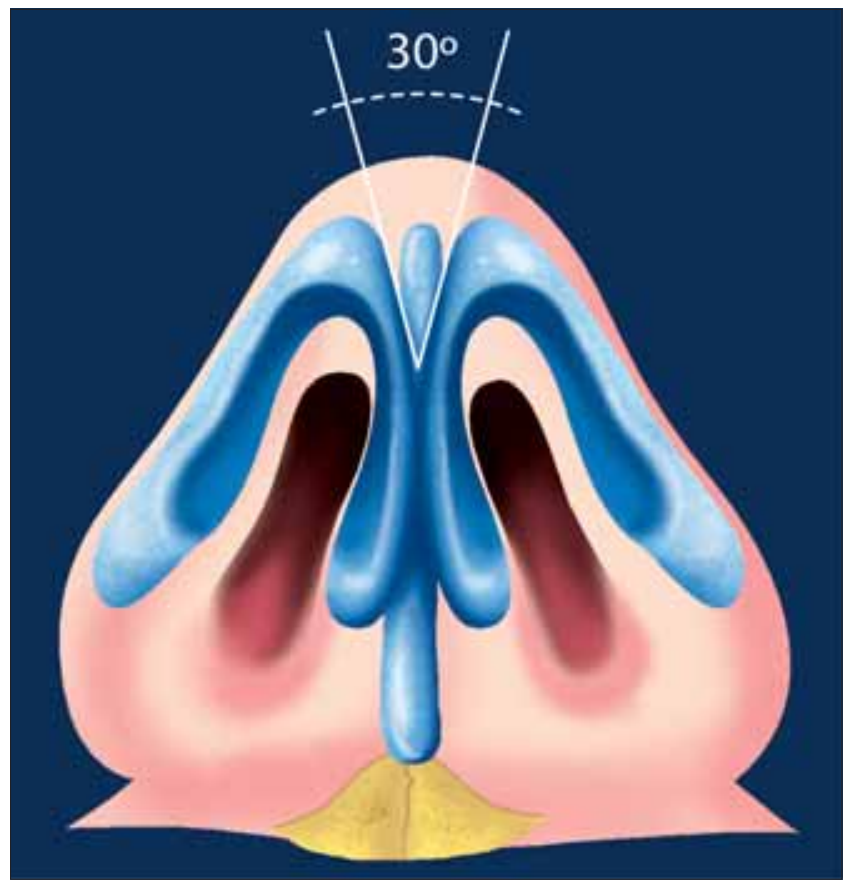

Figure 3. A normal angle of domal divergence.

It is considered normal to have an angle of domal divergence that is less than $30^{\circ}$ (Figure 3) $(4,10)$.

Lateral intercrural suture steps:

1. Subsequent to the displacement of the skin of the LLC using La Garde's maneuver and the dislocation of the cartilage from the skin of the vestibule, introduce the PDS to the junction between the dome and the lateral 
crus (about $3 \mathrm{~mm}$ from the LLC-cephalic border). The thread must be introduced through the cephalic to the caudal margin (Figure 4; Step 1).

2. Move the thread to the contralateral nostril through the transfixant incision (Figure 5; Step 2).

3. Perform Step 1 on the contralateral nostril through the caudal to the cephalic margin, and avoid crossing the threads (Figure 6; Step 3).

4. Return the needle to the nostril in which the stitch was initiated and gradually grip the suture.

\section{Results}

The lateral intercural suture was performed on 64 patients with Caucasian noses through endonasal rhinoseptoplasty using a basic technique without delivery. Pre- and postoperative pictures were evaluated after a 6month evolution period. In all of the cases, an improved nasal tip definition was achieved with results that were satisfactory to both the patients and the surgeon (qualitative, observational, and subjective assessment). None of the patients presented any type of complication.

The present work was approved by the institution's ethics committee (protocol number 004/2008).

\section{DISCUSSION}

The replacement of cartilaginous resection techniques with suture techniques to improve nasal tip definition is a global trend (5). The report regarding sutures that were applied to the nasal tip was originally published by Bahman Guyuron and Ramin A. Behmand in 2003 (6).

Our results were evaluated 6 months postoperatively and had success that was similar to that of the work that was published by Nassif et al (11).

The final result of the suture technique is primarily influenced by factors such as the intrisic force of the cartilage, the degree of tightening of the suture, and the limitation imposed by the soft tissues (ligaments, subcutaneous tissue, and skin).

Skin thickness is another determining factor in the effectiveness of the lateral intercrural suture. In patients with thin skin and sparse subcutaneous tissue the results are more significant. However, in patients with thicker skin and excessive subcutaneous tissue, the lateral intercrural suture may be ineffective, thus requiring a reduction of the angle of domal divergence and of the domal definition by using other techniques, such as the Goldman Technique, transdomal suture, interdomal or medial crus suture, or a

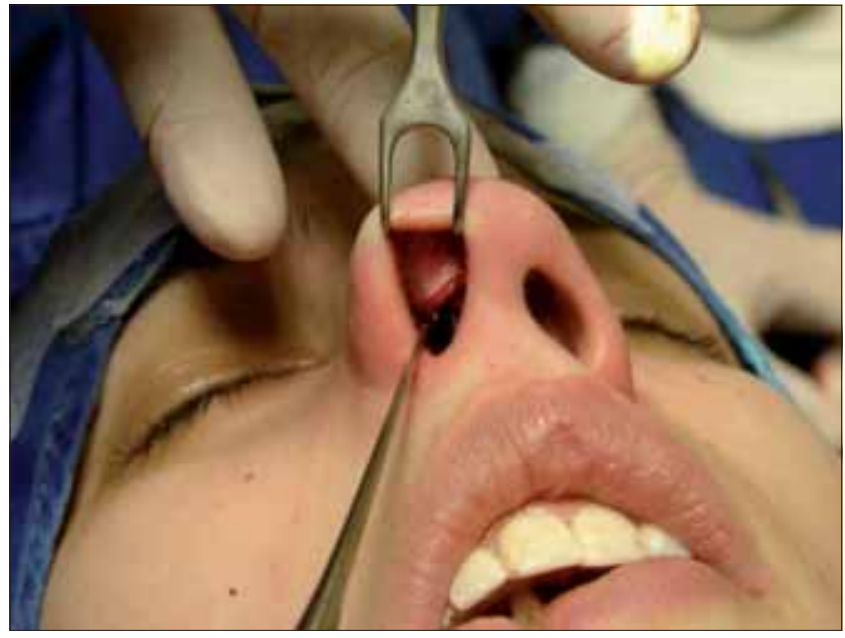

Figure 4. Step 1.

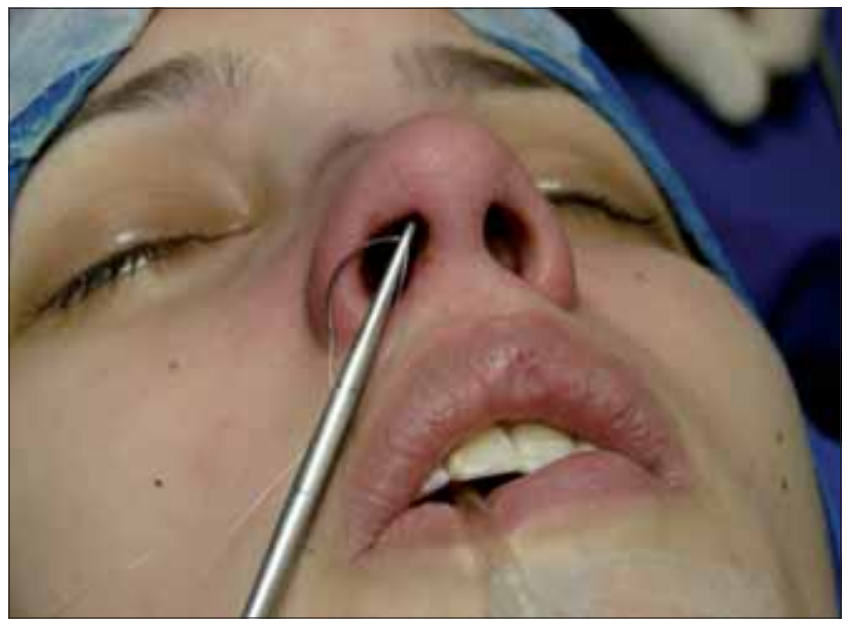

Figure 5. Step 2.

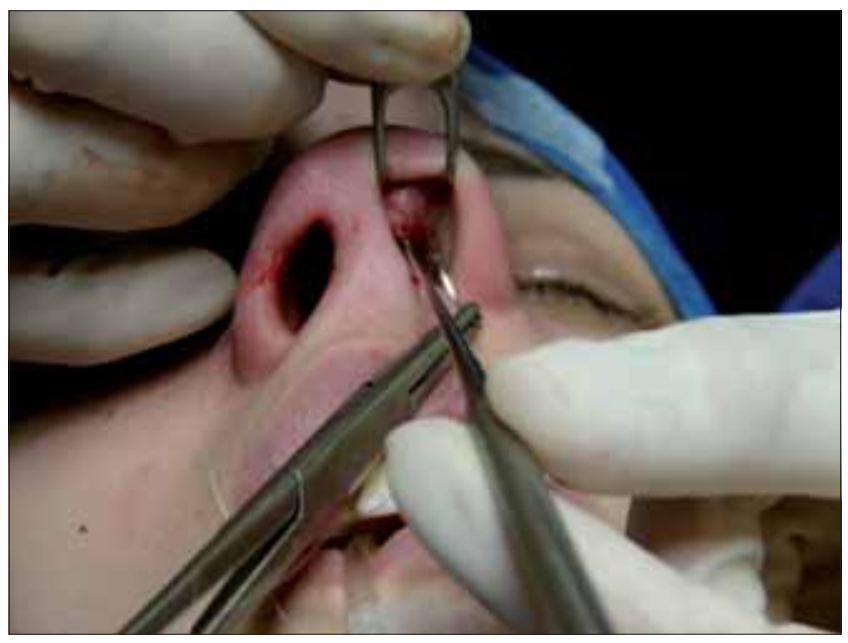

Figure 6. Step 3. 
lateral spanning-type surgery (which compromises more of the lateral crus) (6).

There are some details concerning the lateral intercrural suture technique that must be observed:

1. Slight nasal tip projection, diverging from the results described in the literature (2). The degree of tip definition depends on where the stitch is placed. The more laterally that the suture is placed on the lateral crus, the better the resulting nasal tip projections and definition.

2. Discrete pinching of the supra-alar region, especially in patients with very thin skin and weak supra-alar cartilage, when performed at a distance superior to $2-3 \mathrm{~mm}$ from de nasal dome.

3. Asymmetry of the tip can be observed if the stitches are not placed at corresponding levels.

4. Secondary pollybeak.

The suture can be held in place using long-term absorbable threads (monocryl orPDS) or with non-absorbable threads, with consideration given to the tensile strength and level of absorption of each material. In all of the cases that were described in this work, non-absorbable threads were used, and there were no cases of extrusion or other complications that are described in the literature (abscess, extrusion, asymmetry, or pinching of the tip) (2).

\section{CONCLUSION}

Lateral intercrural suture is an effective method to improve nasal tip definition in the Caucasian nose and can be performed through endonasal rhinoplasty without delivery. This technique had already being reported in the literature through opened and closed access with delivery, but not through closed access with intercartilaginous and septocolumelarincisions.

This suture is easy to perform, predictable, controlled, and extremely useful to the surgeon dedicated to tip surgery. This stitch allows for better management of the tip through basic rhinoseptoplasty, therby minimizing the requirement of surgery procedures through deliveryor the open procedure.

The present study evaluated the improvement of nasal tip definition on the angle of domal divergence using simple suture of the cephalic board and lateral crus of the LLC. We emphasize that each suture has its own precise indication, and the individual surgeon is responsible for assessing and choosing the suture that best fits the needs of the patient.

\section{BiblograPHIC REFERENCES}

1. Maniglia AJ, Maniglia JJ, Maniglia JV. Rinoplastia EstéticaFuncional-Reconstrutora. 1ํㅡㄹ ed. Revinter. 2002, 129-150.

2. Corrado A, Bloom J, BeckerD. Domal Stabilization Suture in Tip Rhinoplasty. Arch Facial Plast Surg. 2009, 11(3):1947.

3. Tardy ME, Brown RJ. Surgical anatomy of the nose. New York: Raven Press, 1990.

4. Rohrich RJ, Adams WP. The Boxy Nasal Tip: Classification and Management Based on Alar Cartilage Suturing Techniques. Plast Reconst Surg. 2001, 1849:107

5. Tebbetts JB. Discussion:nasal tip sutures part I: the evolution. Plast Reconst Surg. 2003, 12(8):1146-9.

6. Guyuron B, Behmand R. Nasal tip sutures part II: the interplays. Plast Reconst Surg. 2003, 12(8):1146-9.

7. LoS, Rowe-Jones J. Suture techniques in nasal tip sculpture: current concepts. J Laryngol Otol. 2007, 121(8):e10.

8. Gruber R, Weintraub J, pomerantz J. Sutura Techniques for Nasal Tip. Aesthetic Surg J. 2008, 28:92-100.

9. Perkins S, Patel A. Endonasal Suture Techniques in Tip Rhinoplasty. Facial plast Surg Clin North Am. 2009, 17(1):4154.

10. Leach JL, Athré. Four suture tip rhinoplasty: A powerful tool for controlling tip dynamics. Otol Head Neck Surg. 2006, 135:227-31.

11. Nassif Filho ACN, Romano G, Ribas DB, Sass SMG, Franceschi E. Refinamento da ponta nasal: técnica de sutura minimamente invasiva para a ponta nasal larga. Arq. Int. Otorrinolaringol. 2011, 15(3):302-307. 